\title{
The Front-Hub of Innovation: updating the classic Fuzzy Front-End to the new approaches of innovation management
}

\author{
Maicon Gouvea de Oliveira, Raoni Barros Bagnob, Glauco Henrique de Sousa Mendesc, Henrique Rozenfeldd, \\ Paulo Tromboni de Souza Nascimento ${ }^{\mathrm{B}}$ \\ Instituto de Ciência e Tecnologia, Universidade Federal de Alfenas \\ bDepartamento de Engenharia de Produç̃ão, Universidade Federal de Minas Gerais \\ 'Departamento de Engenharia de Produção, Universidade Federal de São Carlos \\ dEscola de Engenharia de São Carlos, Universidade de São Paulo \\ eDepartamento de Administração, Universidade de São Paulo \\ e-mails: maicongdo@gmail.com; rbagno@dep.ufmg.br; glauco@dep.ufscar.br; roz@usp.br; tromboni@usp.br
}

\begin{abstract}
There are new drivers concerning the study of innovation being intensively discussed in practice and literature. However, the debate on Fuzzy Front End, hereafter called the Front-End of Innovation (FEI), has not started to address these new drivers yet, maintaining its concepts somewhat static with regards to the innovation field. This paper discusses how the innovation forms (e.g. process, marketing) introduced by new approaches such as business model innovations, design thinking and product-service systems affect the perspectives of classic front-end concepts. As a result of this investigation, a new approach for dealing with the early stages of innovation - The Front-Hub of Innovation (FHI) - is proposed to embrace new forms of innovation other than the traditional product innovation and aimed at supporting the development of value-oriented innovations. The proposal of FHI is described through four dimensions: value creation, organization, process and people.
\end{abstract}

Keywords: fuzzy front end, front and of innovation, front hub of innovation, innovation management, innovation tools.

\section{Introduction}

The fuzzy-front-end, also called front-end of innovation (FEI), includes all the efforts undertaken in the innovation process before a new project is formally approved for development (KHURANA; ROSENTHAL, 1997). In spite of the emergence of new innovation models, the general FEI knowledge, which is widely accepted in academy and industry, remains static to some extent with regards to its foundations.

Traditionally, innovation was primary focused on technical inventions required for new product and process development (WHEELWRIGHT; CLARK, 1992). Then, studies were commonly focused on large companies with well-structured design processes, in which the management of high complexity technical problems was considered the major challenge (e.g. PUGH, 1991). In this context, planning, marketing and technological approaches were employed to deliver helpful information and reduce uncertainties (STOCKSTROM; HERSTATT, 2008).

New forms of innovation have grown in importance recently. They lead to wider definitions for the term innovation, crossing the boundaries of product innovation (BAREGHEH et al., 2009). In addition, new strategies for capturing innovation value have been considered. Among them, it can be highlighted solutions integrating products, services, marketing and processes to deliver innovation (MONT, 2002).

This paper addresses three new forms of innovation: business model, design thinking and product-service system. The business model field study has proposed several processes and methods supporting business model innovations (OSTERWALDER; PIGNEUR, 2002). Design thinking has presented a new solution for addressing customer needs through an iterative and closer perspective (BROWN, 2008). Product-service system has introduced a new approach for delivering value to the market through an integrated offer of products and services (MONT, 2002). Therefore, innovation has grown in scope and complexity of the related studies. Notwithstanding, the front-end literature has not clearly presented studies incorporating these changes. 
In this sense, this paper aims at discussing some of these new innovation forms and how they can affect the traditional concepts of the front-end of innovation. First, it performs a critical analysis of the FEI literature, highlighting its classical frontiers and limitations to deal with the current challenges of innovation development. Then it discusses drivers from the innovation literature, looking for some that can spill over to the FEI field. Finally, as a result, it proposes a broader FEI approach - The Front Hub of Innovation (FHI).

\section{Research method}

This paper is conceptual in nature and follows a deductive approach based on other studies concerning innovation management and the front-end of innovation. It aims at investigating recent drivers for the study of innovation management and how they could affect the early stages of the innovation process, which seem to be still following the traditional innovation literature prescriptions.

In the beginning, a collection of more recent and influential innovation approaches was searched considering academic and industrial perspectives. As a result, the growth of new forms of innovations was noted, encompassing a more holistic view focused on delivering value to customers. This value tends to become independent of the existent technologies, artefacts or processes, but focused on customers' needs (VERGANTI, 2009; BUCHERER et al., 2012; LUSCH; NAMBISAN, 2015). Three relevant approaches were selected in this paper for a first investigation: business model innovation, design thinking and product-service systems. Then, each one of these three innovation approaches were analysed to identify drivers that could lead to new structures or, at least, to new requirements or issues to be addressed in the front-end of innovation.

Once these drivers for the study of innovation were set, they were confronted with the traditional scope of the front-end of innovation, aiming at finding insights and clarifying extant issues. These outcomes became the basis for proposing a new framework to model the front-end of innovation. Several dimensions of FEI were defined to organize the presentation of this new framework. Their development used the framework proposed in Oliveira et al. (2011) as a starting point as well as others related studies: Cooper (1988), Moenaert et al. (1995), Murphy and Kumar (1997), Khurana and Rosenthal (1997, 1998), Zhang and Doll (2001), Koen et al. (2001), Kim and Wilemon (2002), Reid and De Brentani (2004), Poskela (2007), Frishammar et al. (2013).

Finally, the proposal of the framework, named as the Front-Hub of Innovation, is discussed in terms of its potential to improve the understanding and management of the front-end of innovation in face of these new innovation drivers.

\section{The traditional scope of the front-end of innovation (FEI)}

Several studies are assigned to the establishment of the known scope of the front-end of innovation. This study focused on five papers that described its boundaries and primary contents: Cooper (1988), Murphy and Kumar (1997), Khurana and Rosenthal (1997), Koen et al. (2001) and Kim and Wilemon (2002). According to Mendes and Oliveira (2015), these are among the twenty most cited in the Web of Science database for FEI.

Based on these papers, the front-end of innovation, which was also referred by the terms predevelopment and "fuzzy front-end", was seen as the early stages of the new product development process. It would comprise any action or decision made before a new project entered into development. In other words, the moment that defines the transition between the front-end of innovation and the development stage is the commitment to allocate the resources required for the technical project development (COOPER, 1988). Therefore, anything happening from the beginning of the product development process to the commitment decision is considered as being part of the front-end of innovation. Although this scope seems clear, in practice it can become confusing since the commitment moment can differ in terms of each company's product process and of each project's features (OLIVEIRA et al., 2011, 2015).

In addition to the boundaries, before moving ahead in the product development process, there are results or deliverables that should be provided from the front-end of innovation to the development stage. The cited papers present several deliverables, which can be summarized in three primary outcomes: opportunity, product concept and product definition. According to the PDMA glossary (KAHN, 2007): opportunities mean the gaps found in marketing and technological viewpoints that lead to value creation and competitive advantage; product concepts describe the most important features, benefits and requirements related to a product proposal; and product definition involves the establishment of the business and resources perspectives needed for its project implementation. In fact, these three main deliverables represent the core elements that should be created through the FEI activities to support the initiation of the development stage. The amount of information compiled for these deliverables can change in terms of the transition requirements (process and project features). For example, a product classified as a radical innovation, would advance into the development stage with less technical and commercial information than an incremental product, which tend to have substantial prior knowledge 
concerning the required technologies and the commercial model (OLIVEIRA et al., 2011, 2015).

Concerning the FEI management, three points could be highlighted: the knowledge and process management required to support the uncertainty reduction for a single proposal, the management of the FEI team in terms of the required roles and competencies and the management of the portfolio of new product proposals that will be introduced into development.

The knowledge and process management address the intense gathering and analysis of multidisciplinary information used throughout FEI activities. The management of the FEI team encompasses issues related to people commitment, presence of product champions, people interactions and organizational hierarchy. The portfolio management is applied throughout the process and is seen as essential to filter product opportunities, concepts and proposals, ensuring that only those with potential to leverage business strategies will be introduced to the development stage. Some authors (COOPER, 1988; KHURANA; ROSENTHAL, 1997; MURPHY; KUMAR, 1997; KOEN et al., 2001; KIM; WILEMON, 2002) formally include this screening, assessment or selection activities related to portfolio management as FEI activities.

Therefore, the traditional scope of the front-end of innovation defines it as an early stage of the new product development process that ends with the commitment to allocate the resources required for the technical development. Its core results are opportunities, concepts and plans related to new product proposals. During its execution, management processes takes place to support uncertainty reduction, appropriate people involvement and the selection of the best proposals to introduce into development.

\section{Innovation drivers for consideration in the front-end of innovation}

\subsection{New forms of innovation}

As largely known, Schumpeter (1934), in his seminal study on "The Theory of Economic Development", first published in 1911, proposed that innovation could be unfolded in five forms: (i) the introduction of a new good or a new quality of a good (product innovation); (ii) the introduction of new method of production, including a new way of handling a commodity commercially (process innovation); (iii) the opening of a new market (market innovation); (iv) the conquest of a new source of supply of raw material or intermediate input (input innovation); and (v) the carrying out of a new organisation of industry (organisational innovation).

Based on this traditional taxonomy, the central point here is not essentially about new forms of innovation. Notwithstanding, due to some particular historical circumstances related to the development of knowledge in innovation strands - what this paper does not intend to deepen in - some other forms than product/process may sound as "new" in terms of their centrality for many management studies and particularly for the development of FEI approaches.

Essentially, innovation is the result of a process (BAREGHEH et al., 2009; SILVA; BAGNO; SALERNO, 2014; TIDD et al., 2009; BAGNO; SALERNO; SILVA, 2017). Then, investigations about the nature of such a process have established in the last decades the main forum for the development of tools and approaches to manage innovation. In this context, research efforts on New Product Development (NPD) played a central role in early 1990's and contributions like Stage-gates (COOPER, 1993) and Development Funnels (WHEELWRIGHT; CLARK, 1992) strongly influenced the field. However, as stated by Bagno, Salerno and Silva (2017), such studies have been focused mostly on large companies that have well-structured NPD processes and business to customer operations. The typical unity of analysis is a project represented by a structure of components and subsystems, with medium-long life cycles. In this context, social challenges in capturing and diffusing innovation - to give an example - would often be addressed to traditional market research approaches. Process innovations might be induced by new product characteristics and/or simultaneous engineering efforts. In some extent, the same biases were endorsed by references internationally recognized on the measurement of innovation efforts - the Frascati and Oslo Manuals (ORGANISATION..., 2005a; ORGANISATION...; EUROPEAN..., 2005b).

FEI studies were born in the barn of NPD discussions. The classic holistic Front End concept of Khurana and Rosenthal (1998) for instance, choose not to detail the development stage, affirming that this challenge was well faced by other NPD approaches. By one hand, this fact contributed to a faster diffusion of FEI studies but, on the other hand, the limits of NPD studies might certainly have spilled over FEI research in some extent.

In the later 1990's and early 2000's, the diffusion of concepts such as Disruptive Technology (CHRISTENSEN, 1997), Open Innovation (CHESBROUGH, 2003), the Start-up phenomena and its linkages to a fast-growing IT industry - to cite some events - challenged the typical limits of NPD studies and their explanation power of Innovation in organisations. Some problems became more evident: radical innovations concerning not just new technology, but entire business platforms; more plurality in terms of industry sectors, company sizes and interaction forms among organisations; social complexities and other variables entered in debate. Innovation process models, in a great extent, gradually become less prescriptive (in terms of phases, activities, etc.) and shed more light in 
organisational issues (e.g. GOFFIN; MITCHELL, 2010; HANSEN; BIRKINSHAW, 2007; O'CONNOR et al., 2008). Notwithstanding, FEI research seems to have been kept at the margin of these matters.

In this context many authors tried to recover more explicitly the multidimensional perspective of innovation with some adherence to Schumpeter's original statement (e.g. BAREGHEH et al., 2009; TIDD et al., 2009). In turn, Sawhney et al. (2006) identified twelve different dimensions for innovation. Such dimensions are associated with different forms and opportunities for a company to innovate. The authors group these forms in four key dimensions: (i) what is offered by the firm (What); (ii) which customers are served (Who); (iii) the processes employed (How); and (iv) the market points (Where) (Figure 1).

This last approach clearly extrapolates the classic productprocess or even the product-process-organization-marketing perspectives. Such a model represents well the plurality of possible innovation outcomes in an organization, although it has no intention to discuss how to achieve them. Nevertheless, Sawhney et al. (2006) argue that a company may lose many opportunities when a constrained perspective of innovation is present.

\subsection{Business model innovations}

Teece (2010, p.192) defines business models as "[...] the design or architecture of the value creation, delivery, and value capture mechanisms employed by firms in business activities". He also highlights the "[...] importance of business design, particularly in the context of innovation". Moreover, he goes on to tell that there is often a lot of learning and adaptation to be developed or adopted in order to succeed in innovation.

Before Teece (2010), Osterwalder and Pigneur (2002) proposed an ontology for the study of e-business models. An ontology for them is "[...] nothing else than a rigorously

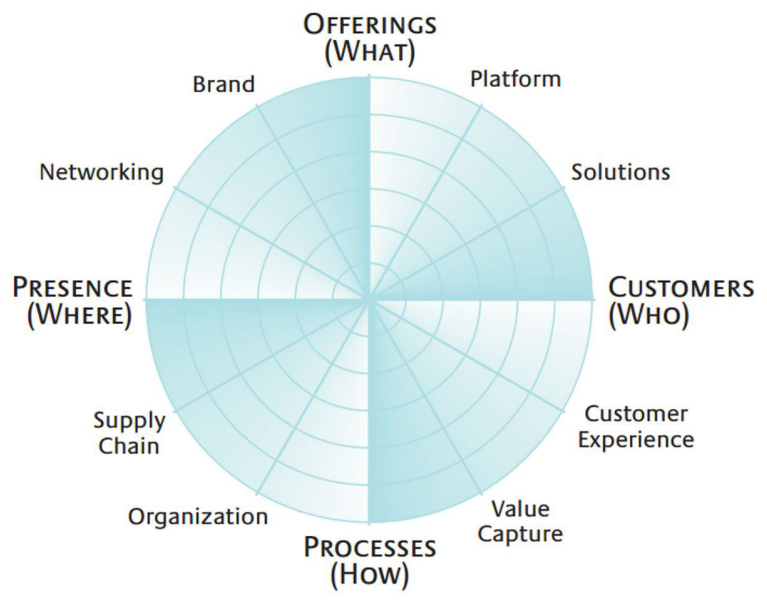

Figure 1. The innovation radar (SAWHNEY et al., 2006). defined framework that provides a shared and common understanding of a domain". They based this definition on Fensel (2001) and its merit would be that it allows for communication among "[...] people and heterogeneous and widely spread application systems". They put four "main pillars" into their ontology: "[...] product innovation, customer relationship, infrastructure management and financials" (OSTERWALDER; PIGNEUR, 2002, p.76). These pillars are further detailed and interrelated in their "rigorous framework", in such a way that a revenue model (based on customer relationships) and a cost model (the result of infrastructure activities) result in the sought business profit.

Next, the aforementioned ontology led to the well-known Business Model Canvas (OSTERWALDER; PIGNEUR, 2010), in which the value proposition turns into costs and revenues that are the foundation of business profit. Of course, the value proposition is itself the interaction of customer relationships with product realization and delivery. Each of these in turn are based on activities and people. Product and costs results from the right activities of right resources, which can be internal or obtained via partners. Sales and revenues come out from well-chosen values proposition that target the right costumer segments via activities concerned with costumer relationships and channels.

Building on the Zott et al. (2011)'s view of a business model as an "activity system" that includes internal processes and "boundary-spanning activities", the business model "boundary-spanning activity system" is a consequence of the designed or implicit "cost and revenue architecture", as is easy to see referring back to Osterwalder and Pigneur (2002). Thus, the front-end of innovation must deal with business model definition, or at least with its identification, together with the definition of product and processes (production, selling, and delivery). The processes' impacts are considered because of costs of the production and delivery processes are closely related to the manner through which revenues are generated. Furthermore, the value creation is linked to the relation between costs and revenues and these in turn are dependent on how products are produced and delivered and how costumers are charged. Zott et al. (2011, p.1034) also suggest that " [...] business models can be a vehicle for innovation as well as a subject of innovation". Therefore, they provide a starting point towards a new concept for the front-end of innovation, in which firm must decide whether it is going to use the current business model or create a new one.

New business models entail changes in the way an operation system create and capture value from innovation. In its turn, changes in value creation, delivery, and capture will affect production as well as commercial activities. The whole operation system may be deeply changed, turning 
technical, managerial or commercial capabilities into rigidities and requiring new ones to be effective. From the front-end's point of view, this means strategic challenges of high complexity and uncertainty. This will then require organizational, marketing, systems and managerial changes which will certainly face resistance.

In the case of small changes, they will not be qualified as changes in the business model. If large enough, they become strategic changes. Thus, the company may start with a modest model change but ends up with a strategic change. As a result, it may have to create new business units, which may compete with old units and require an entire new set of executive views and methods.

In conclusion, business model innovation may create paralyzing conflicts in an organization. In order to avoid them and benefit from the innovation, changes and their impacts must be detected as soon as possible, yet in the front-end of the innovation process. Moreover, it is important to realize that business models, as already cited above, do "[...] involve a more complex, interconnected set of exchange relationships and activities among multiple players [...]" and are not "[...] product market strategy [...] or corporate strategy (ZOTT et al., 2011, p. 1032). They can be viewed as "[...] an integrative framework for strategy implementation [...]" (RICHARDSON, 2008, p.133) and, hence, are an inherent part of innovation development.

\subsection{Design thinking}

Design thinking can be considered as an approach to support innovation with many potential areas of application (KIMBELL, 2011; DORST, 2011). The meaning of design thinking has been changing over the time. Simon (1969) on his book "The Science of the Artificial" elucidates the distinction between the natural sciences logic ("how things are") and the design logic ("how things ought to be"). He states that design reasoning patterns is not restricted to designers. This reasoning differentiates knowledge areas, such as engineering, medicine and business, from sciences. Later, Rowe (1987) identified the design reasoning under the term "design thinking". According to Kimbell (2012) design thinking can be unfolded in three research lines: 1) as a cognitive style, being proposed for non-structured problem solving. In this line, issues relate to identify and explore designers reasoning are considered, such as abductive thinking and reflection-in-action (ROWE, 1987; DORST; CROSS, 2001; CROSS, 2006); 2) as a design theory to create solutions for intricate problems (BUCHANAN, 1992; GOLDSCHMIDT, 1997); 3) as an organizational resource to support user-centred innovation and creativity (BROWN, 2008; MARTIN, 2010; LEAVY, 2010).

This last line became a new trend due to recent popularization efforts, such as those of IDEO (BROWN, 2008). In this context design thinking is considered a human-centred design approach composed by proper mindset and methods, which has been used by many leader enterprises, such as IBM, SAP, Samsung, among others, in order to enhance experience-based innovation. It aims at creating holistic solutions through integrative thinking, empathy, optimism, experimentalism and collaboration (BROWN, 2008; DORST, 2011). Design thinking has been hyped for applications on product development, but also on management and strategic innovation (LEAVY, 2010), education (RAUTH et al., 2010) and social-design (SKLAR; MADSEN 2010). The novelty was to focus not only on technical performance, but in generating innovative value offerings based on usability and satisfaction. Since then, some design thinking methodologies arose, being slightly different from each other due to their fields of application (LIEDTKA; OGILVIE, 2011; STICKDORN; SCHNEIDER, 2011).

A relevant influence of the design thinking approach lies on the use of methods and tools that promote the in depth understanding of the users' behaviour through observation and experimentation. Another practice that has led to success is the employment of simple and agile techniques to enhance fast learning and people collaboration, like brainstorming, charts and stick-notes. Thus, design thinking promotes a mix of innovative processes and people involvement that promote the rise of creative solutions (BROWN, 2008; DORST, 2011).

In comparison to the known innovation process, design thinking could support activities from the front-end of innovation to the conceptual design and test; but it should not replace a design process (GERICKE; MAIER, 2011). Therefore, design thinking is an appropriated approach to be applied in the FEI. This range is primary dependent on the complexity and knowledge concerning the solution in development. For more complex or innovative solutions, its core contribution may end at the front-end, while for less complex and innovative solutions, prototypes can be built and tested with potential customers. Nevertheless, its main contribution can be assigned to its great potential for generating innovative concepts in the front-end through the clarification of relevant needs from stakeholders and integration of perspectives for development, manufacturing, marketing, etc. In sum, design thinking might be applied whenever uncertainty reduction, creativity or problem solving is required.

\subsection{Product-service systems}

Researchers from the marketing field first addressed the idea of offering bundles that combine tangible products and services (LEVITT, 1980). However, it was only after the second half of the 1980's that was observed a real tendency among industrial companies to increase the value for customer and the differentiation from the competition 
through a strong emphasis in services. This tendency characterizes the shift from a product-dominant to a service-dominant logic (VARGO; LUSCH, 2004; BAINES et al., 2009). Nowadays, different terms have been used when a company creates value by offering an integrated package of product and services. Among them, product- service system (PSS) is the most accepted in the literature (OLIVEIRA et al., 2015). According to Goedkoop et al. (1999), PSS must be understood as a system that combines products and services, provides the functionalities necessary to customers and contributes to reduce the environmental impact.

PSS changes company's focus from designing and selling isolate artefacts toward providing a system capable of meeting specific customer needs through the combination of products and services. The adoption of PSS is complex and can lead to changes in organizational structure, processes and culture (CESCHIN, 2013). According to Tan (2010), the development process is one of the most important changes when thinking about PSS. This fact is more evident in the use-oriented and result-oriented PSS types, when product and service design should be integrated in the same design process. Furthermore, in many cases, the PSS development also encompasses the development of a new business model (TAN, 2010).

Mendes et al. (2015) observed that many of these PSS development models focused on the front-end of PSS development, which involves relevant challenges. The front-end of a PSS project is different from designing only a service or a tangible product. In the case of PSS, new activities, new actors, new relationships, new technological artefacts, new cultural and social values, and other elements should be considered through a holistic perspective. Consequently, the existent front-end of innovation models are apparently no longer able to address the complexity involved in designing a PSS, since they tend to assume the existence of appropriate organizational and process structures to implement innovations.

In this sense, several aspects concerning the front-end of innovation should be addressed to tackle PSS. Initially, FEI should address new challenges due to the higher complexity and uncertainty involved in proposing offers that integrate product and service, including: development of activities in different levels and scopes (strategic, process and lifecycle); co-creation with multiple internal and external stakeholders (customers, partners, etc.), and identification and development of the capabilities required for reducing the inherent uncertainties in the early phases of PSS projects.

To conclude, the PSS design process seems to impose challenges to the traditional view of the front-end of innovation. PSS is an integrative solution and, therefore, demands a similar approach in which the front-end needs to perform activities and make decisions embracing integrated choices for the lifecycle in terms of products, services and processes design.

\section{The Front-Hub of Innovation}

Significant changes are imposed to the traditional front-end of innovation process through recent drivers of innovation study. First, this paper described the traditional view of the front-end of innovation, after, it presented a brief discussion about some recent innovation drivers, based mainly in four standpoints: forms of innovation, design thinking, business model innovation and product-service systems. In fact, all of them could be discussed under the umbrella of the new forms of innovation, which is to some extent the proposals of the design thinking, business model innovations and product-service systems. However, they were treated independently in this paper to support a better analysis of each one.

Recovering the aforementioned scope and contents proposed by the traditional front-end of innovation, it becomes evident that it was conceived as an early stage of the new product development process. Consequently, its contents and outcomes give attention to introduce product proposals with potential for technical, market and financial success. The focus on products leads to several features and premises to be adopted in the front-end. Firstly, although important technological changes could be required for some products, the identification of opportunities tend to look for gaps based on the current firm boundaries, i.e., following organizational strategies and processes. For example, this fact could hinder the identification of an opportunity based on the servitization strategy in a manufacturing company or of innovations related to new process arrangements in business models. Concerning the product concept, the creation of the value offer following the traditional product process will probably underestimate a user centred perspective brought to relevance by design thinking or a new commercialization strategy related to a new business model. Then, the project plans, which are used for assessing the viability of development in terms of resources and investments, would require a new assessment approach to, for example, address the impact of product property in product-service systems, when the producer maintain property over the entire product lifecycle, or even to deal with high uncertainty, when new innovation forms are being proposed.

Consequently, a first point for rethinking in the front-end of innovation is its definition as the early stages of the new product development process. The front-end needs to accommodate more than NPD to support the new innovation drivers, actually it needs to be seen as the early stages of the entire innovation process within an organization, whose scope goes further than NPD. Figure 2 seeks to illustrate these debates about innovation and its relation 
with FEI, intending neither to be exhaustive nor definitive in representing all the faces of the whole phenomenon, but to motivate discussion regarding the different levels of innovation analysis and nurture new research.

The central idea in Figure 2 is that significant changes on paradigms in a lower level may have great impacts on higher levels - after some period of time - evidencing a fundamental disruption mechanism. A broad example may be given by the current revolution in information technologies, which has been driving worldwide behaviour transformations and has its roots in the semiconductor and transistor researches, started more than 50 years ago (although the representation also intends to explain transformations in smaller social perimeters). Minor changes at a certain level could also represent newness (circular arrows), but it is not necessarily triggered by big changes in lower levels. At this point, the representation refers to the Schumpeterian idea of creative destruction, once a paradigm in a higher level may sustain incremental innovations for a period, until a disruption changes the game. Looking at the top, any socially adopted innovation - to recover the perspective of Rogers (2003) - feedbacks into the entire environment. In this context, FEI studies are permeated by the dynamics of the four lower levels and has the challenge of concatenating them in an integrated and systematic way to reduce risks and uncertainties concerning disruptive opportunities.

Undoubtedly, recovering Khurana and Rosenthal (1998)'s model, market and technology analyses are better proposed as ongoing activities than punctual missions. Thus, FEI should continually interact with social/market and scientific/technological variables to collect and process relevant data for catalysing new innovation opportunities. Moreover, the idea in Figure 2 does not necessarily represent a phenomenon within a single firm. Different organizations can play distinct roles in each level, promoting disruptive innovations through inter-firm interactions.

Although Oliveira et al. (2011) presented the FEI as the early stages of the product innovation process, they made some advance towards a broader front-end perspective rather than just NPD. They structured the product innovation process in four sub-processes: fuzzy front-end, technology development, new product development and market launch; in which the front-end works as a hub that concentrates any actions dealing with innovation and can interact directly with any of the sub-processes, as shown in Figure 3. Similar approaches can be found in other studies, such as Cooper (1993) or Koen et al. (2001), but they had not described the front-end as a hub of the other innovation sub-processes.

Following this thinking, the front-end needs to assume scope and contents aligned to the multiple forms of innovation possible to occur in an organization, regardless of the current strategies and process. To help with discussing this new approach for the front-end, an initial set of

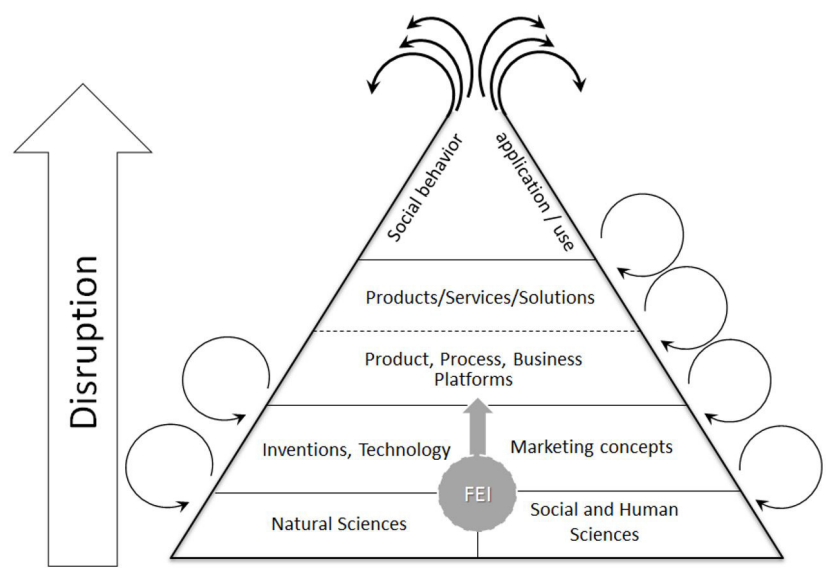

Figure 2. Different levels of innovation phenomenon and the insertion of FEI studies.

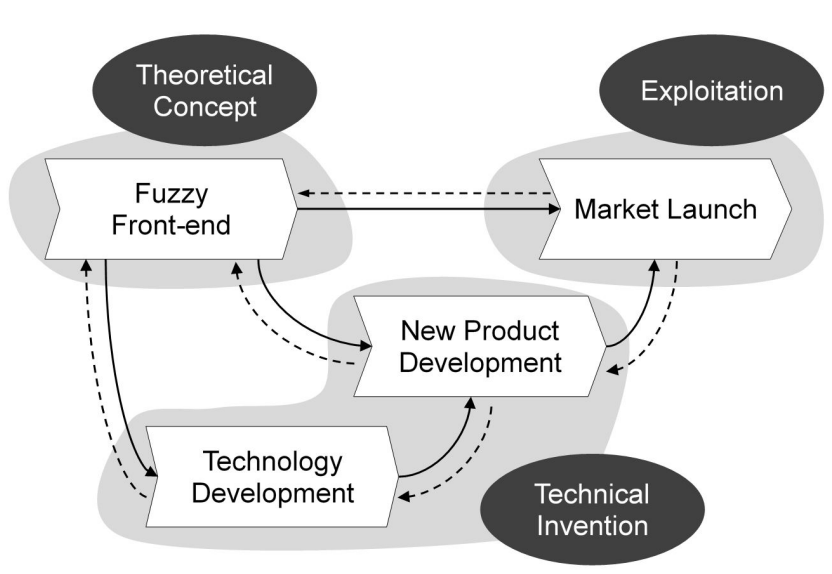

Figure 3. The front-end of innovation as a hub of the innovation process (OLIVEIRA et al., 2011).

dimensions was proposed in this paper. These dimensions were built upon an investigation of traditional front-end papers and can have been influenced by their standpoints. Therefore, the results introduced in this paper represent a proposal still in development, which can be updated. The papers considered in this first proposal were: Cooper (1988), Moenaert et al. (1995), Murphy and Kumar (1997), Khurana and Rosenthal (1997;1998), Zhang and Doll (2001); Koen et al. (2001), Kim and Wilemon (2002), Reid and De Brentani (2004), Poskela (2007), Oliveira et al. (2011) and Frishammar et al. (2013).

The dimensions proposed are:

- Value Creation: focuses on the innovation value chain, i.e., it describes the alignment required throughout organizational structures and the innovation stages;

- Organization: is concerned with the connection between the front-end and other organizational 
structures related directly to the innovation $-R \& D$, marketing, manufacturing, etc. - as well as its connection with those related indirectly: finance, customer relationship, technical assistance, etc;

- Process: deals with the flow of information through activities, methods and tools. It addresses issues related to uncertainty reduction, collaborative work, knowledge management, etc;

- People: represents the definition of the working structure of the participants involved in the front-end in terms of their competencies, skills, assignments, performance, etc..

Below, this paper describes for each of the selected dimensions a vision of how the traditional FEI could be revisited, bringing the Front-Hub of Innovation (FHI) and, then, start to address new forms of innovation. This vision is depicted through a framework in Figure 4.

\subsection{The value creation dimension}

The value creation is a major part of the front-hub, since it represents the fundamental change leading to the consideration of new forms of innovation in the early stages of innovation. As previously presented, innovation in modern economies are not only based on physical products but can handle any artefact or process need to deliver value to customers. Therefore, a complex system of possibilities arises when firms assume as possible to satisfy their customers without considering current restrictions or

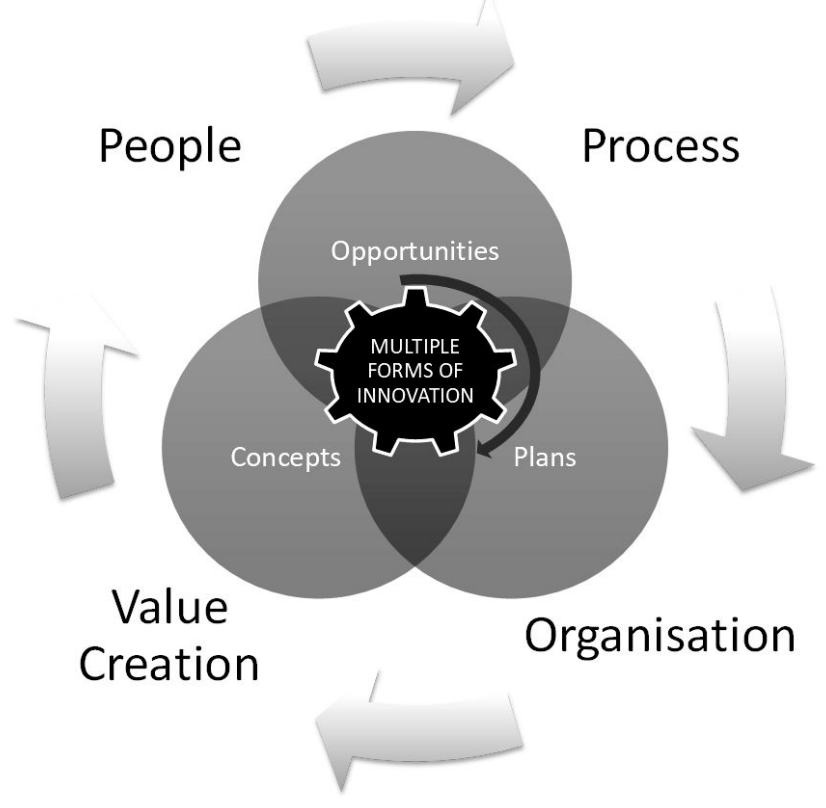

Figure 4. Vision of the Front-Hub of Innovation (FHI). premises. Design thinking drivers are essential at this point, since they show how to focus on clarifying what customers are looking for rather than what firms can offer to them. Furthermore, design thinking breaks the traditional interest in products based solely on physical artefacts and introduce new solutions using mixed artefacts that tend to be more suitable to create value according to customers' perspective. This flexibility is what the front-hub concept uses to allow for working as a central point of the innovation process assigned to develop a new form of innovation.

\subsection{The organization dimension}

This dimension is mainly related to the change in scope from product innovation to any form of innovation with potential relevance and interest for the organization. Because of this change, the front-hub requires access to any organizational structures for gathering information needed for creating innovations. For example, a product-service system which aims at employing online monitoring and closing the lifecycle would require a great interaction with structures related to information and communication technologies, supplying and establishment of partnerships for recycling, remanufacturing or disposal, among others. In this sense, the front-hub is likewise to need a new position within the organizational structure, in which the entire company sees it as a hub for creating and implementing innovations rather than the early stages of new product development.

\subsection{The process dimension}

This dimension involves the embodiment progress from the innovation opportunity, passing through the development of the innovation concept and concluding with the innovation plan. Although there is a clear linear thinking, many studies have clarified that these early stage activities involve constant iterations because of the high level of uncertainties and creativity involved. Thus, although traditional approaches focusing on the front-end include phases and gates to control and screen initiatives of product innovation, the front-hub seems to need even more freedom to interact within a complex system of possible innovations and stakeholders. As a result, managing for reducing uncertainties appears more suitable and relevant than controlling progress and results. The idea of managing for reducing uncertainties - the information processing approach or learning process - have been already used for other studies of the front-end due to its complex and unpredictable features (MOENAERT et al., 1995; OLIVEIRA et al., 2015). In this sense, the employment of methods and tools that support knowledge creation and sharing through the front-hub and the other business processes become more critical to the success of innovations. The point here is: it does not matter whether an activity is 
made prior or after in the process but whether information required to advance towards the degree of uncertainty needed to decide about the development of a particular innovation is achieved.

\subsection{The people dimension}

In the front-hub of innovation, firms need to invite many competencies and skills to become capable of visualizing an extended gap of innovation opportunities, including traditional product-market opportunities, but also other forms of innovation, like business model innovations and servitization. In fact, this initial part of the front-hub tends to become closer to strategic planning activities, since it requires a landscape of potential opportunities for the overall business. However, it should only address strategic issues directed linked to innovation, leaving aside subjects like human resources or financial planning. In sum, the opportunities identification would be closer to a strategic innovation planning, supporting the establishment of opportunities in the innovation landscape. A corresponding team is need at this moment. Once the opportunity is set and clarified, an innovation concept or value is required, which can include several points depending on the form of innovation being addressed. Then, a work structure formed by people who known the organizational processes, technological solutions and the potential customers are invited look for creative solutions capable of delivering value to customers through the use of available processes, products and services or the establishment of new ones. These people would need to be more practical and convergent to achieve an innovation concept. At the end, a project plan or business case should be defined to describe activities, time, resources and results expects from the innovation project. At this point, the team are more likely to help if it has a holistic view of the company strategy and of the industrial competition. Thus, they will be able to decide whether the innovation project should go forward to the development or be hold. At last, new capabilities will have to be developed and realized in FEI for PSS. In general, capabilities refer to a firm's capacity to deploy resources to achieve a desired end (AMIT; SCHOEMAKER, 1993). In the case of PSS, for reducing the inherent uncertainties in the early phases of FEI, it is necessary to develop the organizational capabilities necessary for the service development process, for example.

\section{Final considerations}

This paper presented a discussion concerning the importance of revisiting the foundations of the front-end of innovation to open opportunities for addressing new forms of innovations. It addressed business model innovations, design thinking and product service systems as enablers of new forms of innovation, which have introduced new drivers for studying innovation. Based on this discussion, the traditional front-end of innovation concept was established as focused on dealing with product innovation, which can hinder the development of these new forms of innovations. Therefore, the front-end of innovation would need to revisit its foundations and look for opportunities to integrate them.

Based on this understanding, a new vision for the early stages of the innovation process was proposed - The Front-Hub of Innovation. This vision was then described through four dimensions: value creation, organisation, process and people; and used the three traditional outcomes: opportunities, concepts and plans for generating the innovation proposal required for starting the development stage.

The results of this paper are conceptual in nature and are not exhaustive in terms of the drivers affecting the recent studies of innovation. Hence, further theoretical and empirical research is needed to enhance the proposal presented for the Front-Hub of Innovation.

\section{References}

AMIT, R.; SCHOEMAKER, P. J. H. Strategic assets and organizational rent. Strategic Management Journal, v. 14, n. 1, p. 33-46, 1993.

BAGNO, R. B.; SALERNO, M. S.; SILVA, D. O. Models with graphical representation for innovation management: a literature review. R \& D Management, v. 47, n. 4, p. 637-653, 2017.

BAINES, T. et al. Towards an operations strategy for productcentric servitization. International Journal of Operations \& Production Management, v. 29, n. 5, p. 494-519, 2009.

BAREGHEH, A.; ROWLEY, J.; SAMBROOK, S. Towards a multidisciplinary definition of innovation. Management Decision, v. 47, n. 8, p. 1323-1339, 2009.

BROWN, T. Design thinking. Harvard Business Review, v. 86, n. 6, p. 84-92, 2008.

BUCHANAN, R. Wicked problems in design thinking. Design Issues, v. 8, n. 2, p. 5-21, 1992.

BUCHERER, E.; EISERT, U.; GASSMANN, O. Towards systematic business model innovation: lessons from product innovation management. Creativity and Innovation Management, v. 21, n. 2, p. 183-198, 2012.

CESCHIN, F. Critical factors for implementing and diffusing sustainable product-service systems: insights from innovation studies and companies' experiences. Journal of Cleaner Production, v. 45, p. 74-88, 2013.

CHESBROUGH, H. W. The era of open innovation. MIT Sloan Management Review, v. 44, n. 3, p. 35-41, 2003. 
CHRISTENSEN, C. M. The Innovator's Dilemma: when new technologies cause great firms to fail. Boston: Harvard Business School, 1997.

COOPER, R. G. Predevelopment activities determine new product success. Industrial Marketing Management, v. 17, n. 3, p. 237-247, 1988.

COOPER, R. G. Winning at new products: accelerating the process from idea to launch. Reading: Addison-Wesley Publishing, 1993.

CROSS, N. Designerly ways of knowing. London: Springer, 2006.

DORST, K.; CROSS, N. Creativity in the design process: coevolution of problem-solution. Design Studies, v. 22, n. 5, p. 425-437, 2001.

DORST, K. The core of "design thinking" and its application. Design Studies, v. 32, n. 6, p. 521-532, 2011.

FENSEL, D. Ontologies: silver bullet for knowledge management and electronic commerce. Heidelberg: Springer-Verlag, 2001.

FRISHAMMAR, J.; LICHTENTHALER, U.; RICHTNER, A. Managing process development: key issues and dimensions in the front end. R \& D Management, v. 43, n. 3, p. 213226, 2013.

GERICKE, K.; MAIER, A. Scenarios for coupling design thinking with systematic engineering design in NPD. In: 1st Cambridge Academic Design Management Conference. Cambridge, 2011. p. 1-14.

GOEDKOOP, M. J. et al. Report for Dutch Ministries of environment (VROM) and economic affairs (EZ), v. 36, n. 1, p. 1-122, 1999.

GOFFIN, K.; MITCHELL, R. Innovation management: strategy and implementation using the Pentathlon framework. Basingstoke: Palgrave MacMillan, 2010.

GOLDSCHMIDT, G. Capturing indeterminism: representation in the design problem space. Design Studies, v. 18, n. 4, p. 441-455, 1997.

HANSEN, M. T.; BIRKINSHAW, J. The innovation value chain. Harvard Business Review, v. 85, n. 6, p. 121-130, 2007.

KAHN, K. B. The PDMA glossary for new product development. In: KAHN, K. B. (Ed.). The PDMA handbook of new product development. 2nd ed. USA: John Wiley \& Sons, 2007.

KHURANA, A.; ROSENTHAL, S. R. Integrating the fuzzy front end of new product development. MIT Sloan Management Review, v. 38, n. 2, p. 103-120, 1997.
KHURANA, A.; ROSENTHAL, S. R. Towards holistic "front ends" in new product development. Journal of Product Innovation Management, v. 15, n. 1, p. 57-74, 1998.

KIM, J.; WILEMON, D. Strategic issues in managing innovation's fuzzy front-end. European Journal of Innovation Management, v. 5, n. 1, p. 27-39, 2002.

KIMBELL, L. Rethinking design thinking: part I. Design and Culture, v. 3, n. 3, p. 285-306, 2011.

KIMBELL, L. Rethinking design thinking: part II. Design and Culture, v. 4, n. 2, p. 129-148, 2012.

KOEN, P. et al. Providing clarity and a common language to the "fuzzy front end". Research Technology Management, v. 44, n. 2, p. 46-55, 2001.

LEAVY, B. Design thinking-a new mental model of value innovation. Strategy \& Leadership, v. 38, n. 3, p. 5-14, 2010.

LEVITT, T. Marketing success through differentiation-of anything. Harvard Business Review, v. 58, n. 1, p. 83-91, 1980.

LIEDTKA, J.; OGILVIE, T. Designing for growth: a design thinking tool kit for managers. USA: Columbia University Press, 2011.

LUSCH, R. F.; NAMBISAN, S. Service innovation: a servicedominant logic perspective. Management Information Systems Quarterly, v. 39, n. 1, 2015.

MARTIN, R. Design thinking: achieving insights via the "knowledge funnel". Strategy and Leadership, v. 38, n. 2, p. 37-41, 2010.

MENDES, G. H. et al. Product-Service System (PSS) design process methodologies: a systematic literature review. In: INTERNATIONAL CONFERENCE ON ENGINEERING DESIGN (ICED 15), 20., 2015. Milan. Proceedings... Glasgow: Design Society, 2015. p. 291-300.

MENDES, G. H. S.; OLIVEIRA, M. G. Bibliometric analysis of the front-end of innovation. In: PORTLAND INTERNATIONAL CONFERENCE ON MANAGEMENT OF ENGINEERING AND TECHNOLOGY (PICMET), 15., 2015, Portand. Proceedings... Portand: Portland State University, 2015.

MOENAERT, R. K. et al. R\&D/marketing communication during the fuzzy front-end. IEEE Transactions on Engineering Management, v. 42, n. 3, p. 243-258, 1995.

MONT, O. K. Clarifying the concept of product-service system. Journal of Cleaner Production, v. 10, n. 3, p. 237-245, 2002.

MURPHY, S. A.; KUMAR, V. The front end of new product development: a Canadian survey. $\mathbf{R} \& \mathbf{D}$ Management, v. 27, n. 1, p. 5-15, 1997. 
O'CONNOR, G. C. et al. Grabbing lightning: building a capability for breakthrough innovation. San Francisco: John Wiley \& Sons, 2008.

OLIVEIRA, M. G. et al. A starting point for addressing product innovativeness in the Fuzzy Front-End. International Journal of Technology Intelligence and Planning, v. 7, n. 4, p. 309-326, 2011.

OLIVEIRA, M. G. et al. Decision making at the front end of innovation: the hidden influence of knowledge and decision criteria. R \& D Management, v. 45, n. 2, p. 161-180, 2015.

ORGANISATION FOR ECONOMIC CO-OPERATION AND DEVELOPMENT - OECD. Frascati manual. Paris: OECD Publishing, 2005a.

ORGANISATION FOR ECONOMIC CO-OPERATION AND DEVELOPMENT - OECD; EUROPEAN STATISTICAL OFFICE - EUROSTAT. Oslo manual. Paris: OECD Publishing, 2005b.

OSTERWALDER, A.; PIGNEUR, Y. An e-Business model ontology for modeling e-Business. In: BLED ELECTRONIC COMMERCE CONFERENCE (BLED), 15., 2002, Bled, Sloveni. Proceedings... Bled: University of Maribor, 2002. p. 75-91

OSTERWALDER, A.; PIGNEUR, Y. Business model generation: a handbook for visionaries, game changers, and challengers. John Wiley \& Sons, 2010.

POSKELA, J. Strategic and operative level front-end innovation activities - integration perspective. International Journal of Innovation and Technology Management, v. 4, n. 4, p. 433-456, 2007.

PUGH, S. Total design: integrated methods for successful product engineering. Wokingham, England: AddisonWesley Pub. Co., 1991.

RAUTH, I. et al. Design thinking: an educational model towards creative confidence. In: INTERNATIONAL CONFERENCE ON DESIGN CREATIVITY (ICDC 2010), 1., Kobe, Japan. Proceedings... Glasgow: Design Society, 2010. p. 1-8.

REID, S. E.; DE BRENTANI, U. The fuzzy front end of new product development for discontinuous innovations: a theoretical model. Journal of Product Innovation Management, v. 21, n. 3, p. 170-184, 2004.

RICHARDSON, J. The business model: an integrative framework for strategy execution. Strategic Change, v. 17, n. 5-6, p. 133-144, 2008.

ROGERS, E. M. Diffusion of innovations. USA: The Free Press, 2003.
ROWE, P. Design thinking. Massachusetts: MIT Press, 1987.

SAWHNEY, M.; WOLCOTT, R. C.; ARRONIZ, I. The 12 different ways for companies to innovate. MIT Sloan Management Review, v. 47, n. 3, p. 75-81, 2006.

SCHUMPETER, J. The theory of economic development. Cambridge: Harvard University Press, 1934.

SILVA, D. O. D.; BAGNO, R. B.; SALERNO, M. S. Models for innovation management: review and analysis of the literature. Production, v. 24, n. 2, p. 477-490, 2014.

SIMON, H. The sciences of the artificial. 3rd ed. Massachusetts: The MIT Press, 1969.

SKLAR, A.; MADSEN, S. Global ergonomics: design for social impact. Ergonomics in Design, v. 18, n. 2, p. 4-31, 2010 .

STICKDORN, M.; SCHNEIDER, J. This is service design thinking. Amsterdam: BIS Publishers, 2011.

STOCKSTROM, C.; HERSTATT, C. Planning and uncertainty in new product development. R \& D Management, v. 38, n. 5 , p. 480-490, 2008.

TAN, A. R. Service-oriented product development strategies. 2010. $261 \mathrm{f}$. $\mathrm{PhD}$ (Thesis)-Technical University of Denmark, Lyngby, 2010.

TEECE, D. J. Business models, business strategy and innovation. Long Range Planning, v. 43, n. 2-3, p. 172194, 2010.

TIDD, J.; PAVITT, K.; BESSANT, J. Managing innovation: integrating technological, market and organizational change: USA: John Wiley \& Sons, 2009.

VARGO, S. L.; LUSCH, R. F. Evolving to a new dominant logic for marketing. Journal of Marketing, v. 68, n. 1, p. $1-17,2004$.

VERGANTI, R. Design-driven innovation: changing the rules of competition by radically innovating what things mean. Boston: Harvard Business Press, 2009.

WHEELWRIGHT, S. C.; CLARK, K. B. Revolutionizing product development: quantum leaps speed, efficiency and quality. New York: The Free Press, 1992.

ZHANG, Q.; DOLL, W. J. The fuzzy front end and success of new product development: a causal model. European Journal of Innovation Management, v. 4, n. 2, p. 95-112, 2001.

ZOTT, C.; AMIT, R.; MASSA, L. The business model: recent developments and future research. Journal of Management, v. 37, n. 4, p. 1019-1042, 2011. 